\title{
Communication
}

[Comunicação]

\section{Serology for Brucella abortus in cart horses from an urban area in Brazil}

[Sorologia para Brucella abortus em cavalos de carroça de área urbana do Brasil]

\author{
J.M.A.P. Antunes ${ }^{1}$, S.D. Allendorf ${ }^{1}$, C.M. Appolinário ${ }^{1}$, M.G. Peres ${ }^{1}$, J. H. Perotta ${ }^{2}$, \\ T.B. Neves ${ }^{2}$, I. Deconto ${ }^{2}$, I.R. Barros Filho ${ }^{2}$, A.W. Biondo ${ }^{2,3}$, J. Megid ${ }^{1 *}$ \\ ${ }^{1}$ UNESP - Faculdade de Medicina Veterinária e Zootecnia - Botucatu, SP \\ ${ }^{2}$ Universidade Federal de Paraná - Curitiba, PR \\ ${ }^{3}$ Professor visitante na University of Illinois - Urbana IL, 61802, USA
}

Brucellosis in domestic horses is characterized as an infectious disease of zoonotic potential, caused by Gram-negative bacteria of the genus Brucella (Lucero et al., 2008). Since brucellosis affects several mammalian species, close contact between infected animals and susceptible hosts constitutes a potential dispersion method for the organism, including horses (Ribeiro et al., 2008). Three species of Brucella have been reported as infecting horses: B. abortus, B. suis and B. canis, however, $B$. abortus has been associated as the most common cause of brucellosis in rural horse populations (Ribeiro et al., 2008).

The natural infection may occur through ingestion of infected material, respiratory system or skin wounds, and horses present nonspecific signs such as depression, intermittent fever, muscles stiffness, and reluctance to move; definitive diagnosis is mainly reached by serology (Ribeiro et al., 2008). Equine brucellosis has also been associated with fistulous withers, inflammation of atlantal bursa, carpal bursitis, tenosynovitis, osteomyelitis, osteoarthritis, and rare reproductive disorders (Ocholi et al., 2004; Cvetnic et al., 2005). The bacterium has an apparent predilection for synovial structures and reticuloendotheial tissue, resulting in localized pain and swelling. These swellings may fistulate, and the exudates that drain from them are typically copious and purulent (Ocholi et al., 2004; Cvetnic et al., 2005).

Recebido em 4 de novembro de 2011

Aceito em 1 de agosto de 2013

* Autor para correspondência (corresponding author)

E-mail: jane@fmvz.unesp.br
Cart horses in Brazil are a re-emerging group of animals in urban areas, with owners relying on collecting recycling material for living, with low income and no access to veterinary assistance. According to the local Zoonoses Control Center, Curitiba has approximately 1,500 cart horses, and their owners have daily traffic through the city and surroundings. Brucellosis in horses has been reported in Brazil, with or without association of fistulous withers (Langoni and Silva, 1997; Ribeiro et al., 2003). However, to the author's knowledge, no report to date has focused on re-emerging population of horses in urban areas, such as cart horses. The aim of this study was to evaluate the infection of B. abortus in cart horses of Curitiba and São José dos Pinhais, Paraná, Brazil.

Samples were collected from cart horses of urban areas from April 2005 to June 2006. Their owners spontaneously took all animals to the Zoonoses Control Center. A total of 123 crossbred horses were included in this study. According to the owners, horses were routinely used for carrying carts of recycling material in Curitiba and surroundings areas. Clinical examination was performed in all animals.

Blood samples were collected by vein punction with a vacuum tube system. Sera were separated and stored at $-20^{\circ} \mathrm{C}$ until processing at the laboratory. All serum samples were serologically tested for B. abortus antibodies following the National Program for Control and Eradication of Brucellosis and Tuberculosis (PNCEBT) 
guidance, from the Brazilian Ministry of Agriculture Livestock and Supply (Ministério da Agricultira Pecuária e Abastecimento-MAPA) (Lage et al., 2006). Samples were first screened by Rosa Bengal (RB) test. If lumps were present in the reaction, animal serum was considered reagent and submitted to confirmatory tests (Serum Agglutination Tests- SAT, and 2 mercaptoethanol test, 2-ME).

Eight animals $(6.5 \%)$ were positives for RB and one remained positive in the confirmatory tests. No fistulous withers or joint alteration were found during clinical examination.

Brucellosis is considered one of the most important zoonotic infection in large animals of Latin America with domestic horses presenting a zoonotic potential source of B. abortus (Lucero et al., 2008). Previous reports of brucellosis in horses from Brazil were conducted in rural areas (Silva et al., 2001; Ribeiro et al., 2003; Aguiar et al., 2008). The organism has a predilection for bursa, tendons, ligaments, cartilage and joints, causing severe inflammation (Ribeiro et al., 2008). However, the present study did not find clinical signs of brucellosis in horses. Previous studies also used the RB test, SAT, and 2-ME test for brucellosis for diagnosis of equine brucellosis (Ribeiro et al., 2003; AcostaGonzález et al., 2006; Aguiar et al., 2008). Studies performed in different areas from Brazil showed similar results, with B. abortus identified as the infectious agent (Oliveira et al., 1973; Langoni and Silva, 1997; Silva et al., 2001; Aguiar et al., 2008). However, this is the first time an urban population of horses is surveyed for brucellosis.
Cart horses are common in urban areas of Brazil, where owners daily traffic across big cities and surroundings to collect recycling material. Since direct transmission is the main source of brucellosis infection for human beings this re-emerging population may present public health significance, and should be periodically monitored as sentinels (Lucero et al., 2008). Cart horses have been reportedly infected by Equine Herpesvirus type-1 in Curitiba (Lara et al., 2006). Cohabitation with other species (pigs and cattle) is the likely source of infection for horses (Ribeiro et al., 2003; Ribeiro et al., 2008). It is likely that these animals cohabit with pigs and cattle at the slums and suburbs of large cities. Human infection is under-diagnosed due to low sensitivity of isolation procedures and clinical symptoms (Lucero et al., 2008). Further studies should be conducted in cart horses owners to establish the real risk of exposure and/or infection. According to Brazilian regulations, positive horses for brucellosis should be euthanized (Lage et al., 2006), however, it is not done in Curitiba and São José dos Pinhais. There are a possibility that more positive animals may be present in cart horses from others urban Brazilian areas. Due to the increasing of the concern in recycling materials in big cities from Brazil, the cart horses are particularly important in public health significance.

In summary, cart horses may play an important role as reservoirs and perpetuation of brucellosis in urban areas. The present report provides evidence of brucellosis among cart horses from Brazil, and may serve as an alert for others horse populations in urban areas throughout the world.

Keywords: cart horse; brucellosis, Brucella abortus, cart horse, zoonoses

\section{RESUMO}

Avaliou-se a infecção por Brucella abortus em cavalos de carroça de Curitiba e São José dos Pinhais-PR. Um total de 123 amostras foi submetido ao teste do antígeno tamponado acidificado (ATA), soroaglutinação lenta em tubos (SAL) e prova do 2-mercaptoetanol (2-ME) para confirmação dos resultados. Oito (6,5\%) equinos foram positivos para o ATA e um animal permaneceu positivo ao teste confirmatório. Existem evidências da presença de brucelose entre os cavalos de carroça.

Palavras-chave: cavalos de carroça; brucelose, Brucella abortus, zoonose 


\section{REFERENCES}

ACOSTA-GONZÁLEZ， R.I.; REYES， I.G.; GUTÍERREZ, G.H.F. Prevalence of Brucella abortus antibodies in equines of a tropical region of Mexico. Can. J. Vet. Res., v.70, p.302-304, 2006.

AGUIAR, D.M.; CAVALCANTE, G.T.; LARA, M.C.C.S.H. et al. Prevalência de anticorpos contra agentes virais e bacterianos em equídeos do município de Monte Negro, Amazônia Ocidental Brasileira. Braz. J. Vet. Res. Anim. Sci., v.45, p.269-276, 2008.

CVETNIC, Z.; SPICIC, S.; CURIC, S. et al. Isolation of Brucella suis biovar 3 from horses in Croatia. Vet. Rec., v.156, p.584-585, 2005.

LAGE, A.P.; ROXO, E.; MULLER, E.E. et al. (Ed). In: Programa Nacional de Controle $e$ Erradicação da Brucelose e da Tuberculose Animal. Brasília: Ministério da Agricultura, Pecuária e Abastecimento, 2006. 188p.

LANGONI, H.; SILVA, A.V. Comportamento sorológico de aglutininas anti-Brucella em soro de equídeos. Rev. Bras. Med. Vet., v.19, p.85-87, 1997.

LARA, M.C.C.S.; FURMAN, K.E.; BARROS FILHO, I.R. et al. Detection of antibodies against equine arteritis virus (EVAV) and equine herpesvirus type 1 (EHV-1) in cart horses from Curitiba and Surroundings, Southern Brazil. Arch. Vet. Sci., v.11, p.11-14, 2006.
LUCERO, N.E.; AYALA, S.M.; ESCOBAR, G.I. et al. Brucella isolated in humans and animals in Latin America from 1968 to 2006. Epidemiol. Infect., v.136, p.496-503, 2008.

OCHOLI, R.A.; BERTU, W.J.; KWAGA, J.K.P. et al. Carpal bursitis associated with Brucella abortus in a horse in Nigeria. Vet. Rec., v.155, p.566-567, 2004.

OLIVEIRA, Q.C.; MOREIRA, V.S.; LIMA, C.S. Brucelose em equídeos. Rev. Med., v.9, p.93106, 1973.

RIBEIRO, M.G.; NARDI JÚNIOR, G.; MEGID, J. et al. Anti-Brucella abortus agglutinins in serum and secretion of fistulous withers in horses. Arq. Bras. Med. Vet. Zootec., v.55, p.99101, 2003.

RIBEIRO, M.G.; MOTTA, R.G.; ALMEIDA, C.A.S. Brucelose equina: aspectos da doença no Brasil. Rev. Bras. Reprod. Anim., v.32, p.83-92, 2008.

SILVA, L.A.F.; ACYPRESTE, C.S.; EURIDES, D. et al. Seroprevalence of brucellosis in horses with withers or atlantal bursitis. Arq. Cienc. Vet. Zool., v.4, p.19-23, 2001. 